\title{
Evaluation of Wood Sorption Models and Creation of Precision Diagrams for the Equilibrium Moisture Content
}

\section{Ocjena sorpcijskih modela drva i izrada preciznih dijagrama za ravnotežni sadržaj vode u drvu}

Review paper • Pregledni rad

Received-prispjelo: 8. 4. 2011.

Accepted-prihvaćeno: 22. 11. 2011.

UDK: $630 * 812.226$

doi:10.5552/drind.2011.1115

\begin{abstract}
Precision has been evaluated of the 10 most often used wood sorption models, available in literature, for the calculation of the equilibrium moisture content of wood given a change in temperature within the range from $0{ }^{\circ} \mathrm{C}$ to $200{ }^{\circ} \mathrm{C}$ and in the relative humidity of the surrounding air environment from $0 \%$ to $100 \%$. Based on the results of the critical analysis, an argumentative selection has been done of the models that can be purposefully used for the computer determination of wood equilibrium moisture content in contemporary systems for model-based or model predictive automatic control of different processes of hydrothermal treatment of wood and wood materials. With the help of these models, diagrams have been created for precise determination of wood equilibrium moisture content. The established high precision of both the Simpson and Ray et al. models and the Garsia model, which we have refined, makes them user friendly for model-based or predictive automatic systems and other engineering applications in the respective temperature ranges specified in the paper.
\end{abstract}

Keywords: wood sorption models, mathematical description, equilibrium moisture content, temperature, relative humidity, model-based control

SAŽETAK • U radu se ocjenjuje točnost deset u literaturi najčešće primjenjivanih sorpcijskih modela za izračun ravnotežnog sadržaja vode u drvu za raspon temperature od 0 do $200{ }^{\circ} \mathrm{C}$ i relativne vlažnosti okolnog zraka od 0 do 100\%. Na temelju kritičke analize napravljena je selekcija modela koji se mogu upotrijebiti za računalno određivanje ravnotežnog sadržaja vode u drvu u sklopu suvremenih sustava za automatsku kontrolu procesa hidrotermičke obrade drva i drvnih materijala. Uz pomoć odabranih modela napravljeni su dijagrami za prezicno određivanje ravnotežnog sadržaja vode u drvu. Dokazana visoka točnost Simpsonova i Rayeva te Garsíjeva modela, uz napravljene dorade modela, čine te modele jednostavnima za primjenu u automatskim sustavima za upravljanje i druge inženjerske primjene u rasponu temperatura specificiranih u radu.

\footnotetext{
${ }^{1}$ Author is professor at Faculty of Forest Industry, University of Forestry, Sofia, Bulgaria.

${ }^{1}$ Autor je profesor Fakulteta šumske industrije Šumarskog sveučilišta, Sofija, Bugarska.
} 
Ključne riječi: sorpcijski modeli drva, matematički opis, ravnotežni sadržaj vode, temperatura, relativna vlažnost, upravljanje na temelju modela

\section{INTRODUCTION}

1. UVOD

In practice the most widely used method for the control of various processes of hydrothermal treatment of wood materials is based on ensuring scientifically based change during the time of wood equilibrium moisture content in a function of temperature $t$ and relative humidity $\varphi$ of the processing medium. In any combination of values $t$ and $\varphi$ after a certain time the wood reaches a state of stability and thus its moisture content is constant and it either receives, or emits moisture, i.e. it is in equilibrium with the surrounding environment. This moisture is defined as wood equilibrium moisture content $U_{\text {EMC }}$.

The instructions for exploitation of the systems for automatic control of the processes of convective drying and other kinds of hydrothermal treatment of wood materials, as a rule consist of empirical tables and/or diagrams for the dependency of $U_{\text {EMC }}$ on $t$ and $\varphi$. The implementation of modern control of technological processes with the help of programmable controllers or computers allows for the determination of $U_{\text {EMC }}$ with the help of software. For this purpose, it is necessary to have a precise mathematical description of $U_{\text {EMC }}$ depending on $t$ and $\varphi$.

The effective control of $U_{\text {EMC }}$ can ensure a significant reduction of the duration and specific energy expenses of the processes of hydro-thermal treatment of wood, as well as deviations in the final moisture content in the separated materials, subjected to such treatment.

The aim of the present paper is to analyze the precision of wood sorption models, found in reference literature and most often used, and to provide an argumentative choice of those most suitable for use as mathematical description of $U_{\text {EMC }}$ in the systems of model-based and model predictive automatic control of various processes of hydrothermal treatment of wood and wood-composite materials (Deliiski, 2009b; Shubin, 1990; Trebula and Klement, 2002; Videlov, 2003).

\section{MATERIAL AND METHODS}

2. MATERIJAL I METODE

In the reference literature we found 10 most often used mathematical models of the sorption behavior of wood, with the help of which $U_{\text {EMC }}$ can be calculated depending on temperature and relative humidity of the air. Chronologically, these models are published in the following way:

Model 1: Brunauer, Emmett, and Teller (1938);

Model 2: Hailwood and Horrobin (1946) - one hydrate model;

Model 3: Hailwood and Horrobin (1946) - two hydrate model;

Model 4: Malmquist (1958);
Model 5: King (1960);

Model 6: Day and Nelson (1965);

Model 7: Kaplan (1972);

Model 8: Simpson (1991);

Model 9: Garsía (2002);

Model 10: Ray et al. (2007).

Vidal and Cloutier (2005) make a relative assessment of the precision of the models 1, 2, 3, 4, 5, 6 and 9 in relation to experimental data published in the literature for $U_{\text {EMC }}$ at five different values of relative humidity: $40,52,65,75$ and $85 \%$ for the temperature ranging between $0{ }^{\circ} \mathrm{C}$ and $160{ }^{\circ} \mathrm{C}$. The authors determine, and our calculations also prove, that the models 1,2 and 5 give the least accuracy. Because of this fact, these models are not evaluated below, and the calculations in the present paper at $0 \% \leq \varphi \leq 100 \%$ are limited to assessing the precision of the models $3,4,6,7,8,9$ and 10 within the range $0{ }^{\circ} \mathrm{C} \leq t \leq 100{ }^{\circ} \mathrm{C}$ and of the model $3,4,6,7$ and 9 within the range $100{ }^{\circ} \mathrm{C} \leq t \leq$ $200{ }^{\circ} \mathrm{C}$. The models 8 and 10 represent regression equations, which indicate the change in $U_{\mathrm{EMC}}$ depending on $t$ and $\varphi$ only within the range from $0^{\circ} \mathrm{C}$ to 100 ${ }^{\circ} \mathrm{C}$ and are not applicable in the range $100{ }^{\circ} \mathrm{C} \leq t \leq 200$ ${ }^{\circ} \mathrm{C}$ (Deliiski et al, 2009a).

In the equations of the models below $\varphi$ is labeled as the relative vapor pressure, which is the result of division by 100 so as to get the relative air humidity expressed in percentages. In the models 3, 4 and 6 thermo-dynamical temperature $T$ (in $\mathrm{K}$ ) is taken into account and in the models 7, 8, 9 and 10 - the temperature $t$ (in $\left.{ }^{\circ} \mathrm{C}\right)$.

The calculated values of wood equilibrium moisture content $U_{\mathrm{EMC}}$ of the models $3,6,7,8$ and 10 are expressed with dimension percentages, and in the models 5 (Malmquist, 1958) and 9 (Garsía, 2002) $U_{\text {EMC }}$ is expressed in $\mathrm{kg} \cdot \mathrm{kg}^{-1}$ and in order to express this in percentage terms, the obtained results have to be multiplied by 100 .

The models 3, 4, 6, 7, 8, 9 and 10 are presented through the following equations:

Model 3: Hailwood and Horrobin (1946) - two hydrate model

$$
U_{\mathrm{EMC}}=\frac{1800}{M_{\mathrm{p}}}\left(\frac{K \varphi}{1-K \varphi}+\frac{K_{1} K \varphi+2 K_{1} K_{2} K^{2} \varphi^{2}}{1+K_{1} K \varphi+K_{1} K_{2} K^{2} \varphi^{2}}\right)
$$

where 1800 is the molecular weight of water $\mathrm{x} 100$, $\mathrm{g} \cdot \mathrm{mol}^{-1} ; M_{\mathrm{p}}$ - molecular weight of a polymer unit that forms a hydrate, $\mathrm{g} \cdot \mathrm{mol}^{-1}$.

As a result of the parameterization procedure Vidal and Cloutier (2005) deduct the following equations for the calculation of the coefficients on the right side of equation (1):

$$
\begin{gathered}
M_{\mathrm{p}}=-330.03+2.3468 T+0.00028368 T^{2}, \\
K=0.68405+0.00047238 T-3.3289 .10^{-8} T^{2},
\end{gathered}
$$


....... Deliiski: Evaluation of Wood Sorption Models and Creation of Precision Diagrams...

$$
\begin{gathered}
K_{1}=19.641-0.0587818 T+4.05 .10^{-5} T^{2}, \\
K_{2}=2.6172+0.0016795 T-0.000006414 T^{2} .
\end{gathered}
$$

Model 4: Malmquist (1958)

$$
U_{\mathrm{EMC}}=\frac{K_{1}}{1+K_{2}\left(\frac{1}{\varphi}-1\right)^{\frac{K}{3}}},
$$

where, according to the author

$$
\begin{gathered}
K=2.2885-0.0016742 T+2.0637 .10^{-6} T^{2} . \\
K_{1}=0.40221-0.00009736 T-5.8964 .10^{-7} T^{2}, \\
K_{2}=2.6939+0.018552 T-2.1825 .10 T^{2} .
\end{gathered}
$$

Model 6: Day and Nelson (1965)

$$
U_{\mathrm{EMC}}=\frac{K_{1}}{1+K_{2}\left(\frac{1}{\varphi}-1\right)^{\frac{K}{3}}},
$$

where $K_{1}, K_{2}, K_{3}, K_{4}$ are constants, for which Avramidis (1989) has determined the following values:

$K_{1}=-3.4 \cdot 10^{-17} ; K_{2}=9.98 ; K_{3}=300$ and $K_{4}=-0.93$.

Model 7: Kaplan (1972)

$$
U_{\mathrm{EMC}}=10,6^{\varphi}(3.27-0.015 t),
$$

Model 8: Simpson (1991)

$$
U_{\mathrm{EMC}}=\frac{1800}{M_{\mathrm{p}}}\left(\frac{K_{1} \varphi}{1-K_{1} \varphi}+\frac{K_{2} K_{1} \varphi+2 K_{3} K_{2} K_{1}^{2} \varphi^{2}}{1+K_{2} K_{1} \varphi+K_{3} K_{2} K_{1}^{2} \varphi^{2}}\right)
$$

where, according to the author:

$$
\begin{gathered}
M_{\mathrm{p}}=349+1.29 t+1.35 .10^{-2} t^{2}, \\
K_{1}=0.805+7.36 .10^{-4} t-2.73 .10^{-6} t^{2}, \\
K_{2}=6.27-9.38 .10^{-3} t-3.03 .10^{-4} t^{2}, \\
K_{3}=1.91+4.07 .10^{-2} t-2.93 .10^{-4} t^{2} .
\end{gathered}
$$

Model 9: Garsía (2002)

$$
U_{\mathrm{EMC}}=K\left[\left(\frac{K_{5}}{\varphi}\right)^{K_{7}}-1\right]^{-\frac{1}{K_{6}}},
$$

where, according to the author:

$$
\begin{gathered}
K=K_{1} \exp \left[-\left(\frac{t+K_{2}}{K_{3}}\right)^{K_{4}}\right], \\
K_{1}=1865.75 .10^{-4} ; K_{2}=1025 ; K_{3}=1163.31 ; \\
K_{4}=12.7441 ; K_{5}=1.09603 ; K_{6}=2.36069 \text { and } \\
K_{7}=1.84447 .
\end{gathered}
$$

Model 10: Ray et al. (2007)

In 2007 Ray et al. (2007) published their results of research on the precision of the calculation of $U_{\mathrm{EMC}}$ with the help of the Simpson model, i.e. using the equations $(12) \div(16)$. They came to the conclusion that the average square error, when determining $U_{\text {EMC }}$ by these equations in the range $0{ }^{\circ} \mathrm{C} \leq t \leq 44{ }^{\circ} \mathrm{C}$, is equal to $\pm 0.5 \%$, but in the range $44{ }^{\circ} \mathrm{C}<t \leq 100{ }^{\circ} \mathrm{C}$ it increases to $\pm 1.5 \%$.

This inspired the authors to propose their regression equation for the computation of $U_{\text {EMC }}$ depending on $\varphi$ and $t$ in the range $44{ }^{\circ} \mathrm{C}<t \leq 100{ }^{\circ} \mathrm{C}$. Ray et al (2007) present the equation for the determination of $U_{\text {EMC }}$ depending on $\varphi$ and on temperature $t$ expressed in degrees Fahrenheit. After substituting $t$ in the known relation from degrees Fahrenheit to degrees Celsius, namely: $t\left[{ }^{\circ} \mathrm{F}\right]=1,8 t\left[{ }^{\circ} \mathrm{C}\right]+32$, we obtained the following equation for determining $U_{\mathrm{EMC}}$ for the range $0 \% \leq$ $\varphi \leq 100 \%$ and $44{ }^{\circ} \mathrm{C}<t \leq 100{ }^{\circ} \mathrm{C}$ :

$$
U_{\mathrm{EMC}}=\left(\begin{array}{l}
7.30548+11.64339 \varphi_{\mathrm{c}}-0.00792 t_{\mathrm{c}} \\
-0.37436 K_{1}-0.39562 K_{3}+0.06902 K_{2}^{2} \\
+0.00518 K_{3}^{2}+0.00129 K_{1} K_{4} \\
-0.00048153 K_{2} K_{4}+0.61135 K_{5}
\end{array}\right)^{2}
$$

where:

$$
\begin{gathered}
K_{1}=0.0001+0.0025 t_{\mathrm{c}}+0.0007 t_{\mathrm{c}}^{2} \\
K_{2}=0.2+0.06 t_{\mathrm{c}}-0.00004 t_{\mathrm{c}}^{2} \\
K_{3}=14.0+35.5 \varphi_{\mathrm{c}}+20.7 \varphi_{\mathrm{c}}^{2} \\
K_{4}=1.0+0.01 \varphi_{\mathrm{c}} t_{\mathrm{c}}+0.1 \varphi_{\mathrm{c}}^{2} t_{\mathrm{c}}^{2} \\
K_{5}=\frac{1+K_{2}+K_{3}}{K_{1}^{2}+K_{3}^{2}}
\end{gathered}
$$

$t_{\mathrm{c}}=1.8 t-125.5$ - centered (named by the authors) value of $t,{ }^{\circ} \mathrm{C}$ (Ray et al, 2007),

$\varphi_{\mathrm{c}}=\varphi-0.58537037$ - centered value of $\varphi,($ Ray et al, 2007).

The authors (Ray et al, 2007) prove that the error of the results obtained from the equations $(19) \div(24)$, for the ranges $0 \% \leq \varphi \leq 100 \%$ and $44{ }^{\circ} \mathrm{C}<t \leq 100{ }^{\circ} \mathrm{C}$, is smaller by $44 \%$ than the error of the results obtained from the equations $(12) \div(16)$.

\section{RESULTS AND DISCUSSION 3. REZULTATI I RASPRAVA}

For the solution of the models $3,4,6,7,8,9$ and 10 , which include the equations $(1) \div(24)$, we created a program in the computing environment of VISUAL FORTRAN PROFESSIONAL supported by Windows.

With the help of the program, we calculated the values of $U_{\mathrm{EMC}}$ when $t$ changes from $0{ }^{\circ} \mathrm{C}$ to $200{ }^{\circ} \mathrm{C}$ in steps of $0.1{ }^{\circ} \mathrm{C}$ and $\varphi$ from $0 \%$ to $100 \%$ in steps of $0.1 \%$. The results are compared with the corresponding experimental data from the literature (FPL 1999) and (Kubojima et al, 2003) related to the change of $U_{\text {EMC }}$ depending on $t$ and $\varphi$ (Table 1, 2 and 3).

During the analysis of the results obtained, we did not take into consideration the sorption hysteresis, 
possible variations of the sorption isotherms due to different species of wood used for the determination of the sorption isotherms taken from the literature, and variations due to internal structures such as heartwood and sapwood (Ball et al, 2001; Pervan, 2000).

As the experimental data in FPL (1999) are temperatures expressed in degrees Fahrenheit, in the very first column of both Table 1 and 2, the values of $t$ are given in degrees Celsius, which were assigned to $t$ during the experiments. Since the experiments are conducted using different values of $\varphi$, not always corresponding to $\varphi$ values in Table 1, 2 and 3, in the very last column of the tables the exact experimental values of $U_{\text {EMC }}$ (when the experimental and computed values of $\varphi$ coincide) are not marked with an asterix sign (*), while the interpolated experimental values of $U_{\text {EMC }}$ (when the experimental and computed values of $\varphi$ do not coincide) are shown with an asterix sign $(*)$.

\subsection{Change of $U_{\mathrm{EMC}}$ in the range $0 \leq t \leq 100^{\circ} \mathrm{C}$}

3.1. Promjena $U_{\mathrm{EMC}} \mathrm{u}$ rasponu temperature $0 \leq t \leq 100^{\circ} \mathrm{C}$

The computed values of $U_{\text {EMC }}$ according to the models 3, 4, 6, 7, 8, 9 and 10 and their corresponding experimental values from FPL (1999) are given in Table 1 (for the range $0 \% \leq \varphi \leq 50 \%$ ) and in Table 2 (for the range $60 \% \leq \varphi \leq 94 \%$ ).

The analysis of the data from Table 1 and 2, and also of the others not given in these tables, shows that the experimentally established change in $U_{\mathrm{EMC}}$ depending on $\varphi$ is described most accurately by the Simpson model within the range $0{ }^{\circ} \mathrm{C} \leq t \leq 50{ }^{\circ} \mathrm{C}$ and by the model of Ray et al. within the range $50{ }^{\circ} \mathrm{C}<t \leq 100{ }^{\circ} \mathrm{C}$. The absolute error of $U_{\text {EMC }}$, which is obtained from these models in the given temperature ranges, is within the limits of $\pm 0.4 \%$ at $0 \% \leq \varphi \leq 50 \%$ and $\pm 0.7 \%$ at $60 \%$ $\leq \varphi \varphi \leq 94 \%$. Figure 1 shows the isotherms of $U_{\mathrm{EMC}}$ derived using these two models when $t=0,20,40,60$, 80 and $100{ }^{\circ} \mathrm{C}$ with the change of $\varphi$ from 0 to $100 \%$.

The next most accurate model is that of Garsía with the absolute error within the limits of $\pm 0.7 \%$ at $0 \% \leq \varphi \leq 50 \%$ and $0.9 \%$ at $60 \% \leq \varphi \leq 94 \%$. The models of Hailwood and Horrobin-2 and of Malmquist give very close results with the absolute error within the limits of $\pm 0.7 \%$ at $0 \% \leq \varphi \leq 50 \%$ and $\pm 1.2 \%$ at $60 \%$ $\leq \varphi \leq 94 \%$. The biggest inaccuracy is observed in the models of Day \& Nelson and of Kaplan - they give the results of $U_{\text {EMC }}$ higher than the experimental ones within the limits of $3.3 \%$.

It should be noted that all of the examined models reflect very well the complicated character of change in $U_{\mathrm{EMC}}$ depending on $t$ and $\varphi$ as shown in Fig. 1. The indicated limits of change of the absolute error in determining $U_{\text {EMC }}$ based on all the models refer to the relatively high values of $\varphi$. With smaller values of $\varphi$, the absolute error, as a rule, significantly decreases. Only for Kaplan's model the opposite dependency can be observed - the more the value of $\varphi$ decreases, the more the absolute error increases and reaches $+3.3 \%$ at $t=0{ }^{\circ} \mathrm{C}$ and $\varphi=0 \%$.

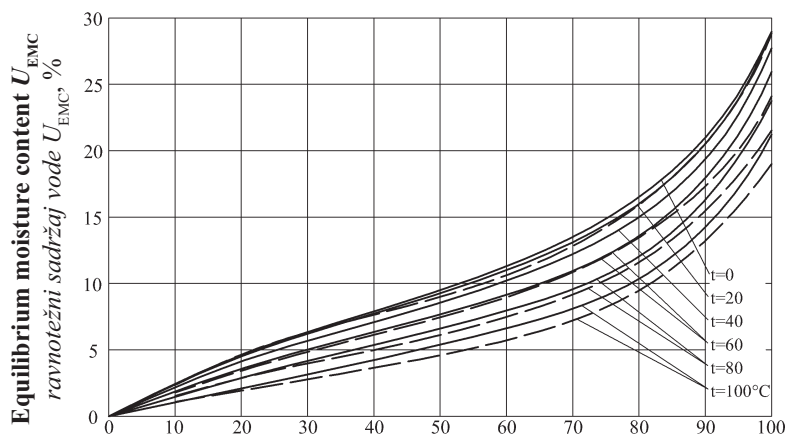

Relative humidity $\varphi_{\mathrm{A}} /$ relativna vlaga zraka $\varphi_{\mathrm{A}}, \%$

Figure 1 Isotherms of the change of $U_{\mathrm{EMC}}$ calculated based on the Simpson model (full lines), and based on a combination of both Simpson model - at $t=0,20$ and $40^{\circ} \mathrm{C}$ and Ray et al. model - at $t=60,80$ and $100{ }^{\circ} \mathrm{C}$ (dotted lines) Slika 1. Izoterme promjene ravnotežnog sadržaja vode izračunane na temelju Simpsonova modela (pune linije), i na temelju kombinacije Simpsonova modela za temperature $t=0,20 \mathrm{i} 40^{\circ} \mathrm{C}$ te Rayeva modela za temperature $t=60,80$ i $100{ }^{\circ} \mathrm{C}$ (iscrtkane linije)

Figure 2 shows a precise diagram of the change of $U_{\text {EMC }}$ depending on $\varphi$ and $t$ within the range $0 \% \leq \varphi$ $\leq 100 \%$ and $0{ }^{\circ} \mathrm{C}<t \leq 100{ }^{\circ} \mathrm{C}$. The diagram curves are built based on the results obtained by the Simpson model at $0{ }^{\circ} \mathrm{C} \leq t \leq 50{ }^{\circ} \mathrm{C}$, and with the help of Ray et al. model when $50{ }^{\circ} \mathrm{C}<t \leq 100{ }^{\circ} \mathrm{C}$. This diagram shows the experimentally established relations of $U_{\text {EMC }}$ depending on $t$ and $\varphi$ with a higher precision in comparison with analogous diagrams, usually referred to in the literature (Shubin, 1990; Trebula and Klement, 2002; Videlov, 2003).

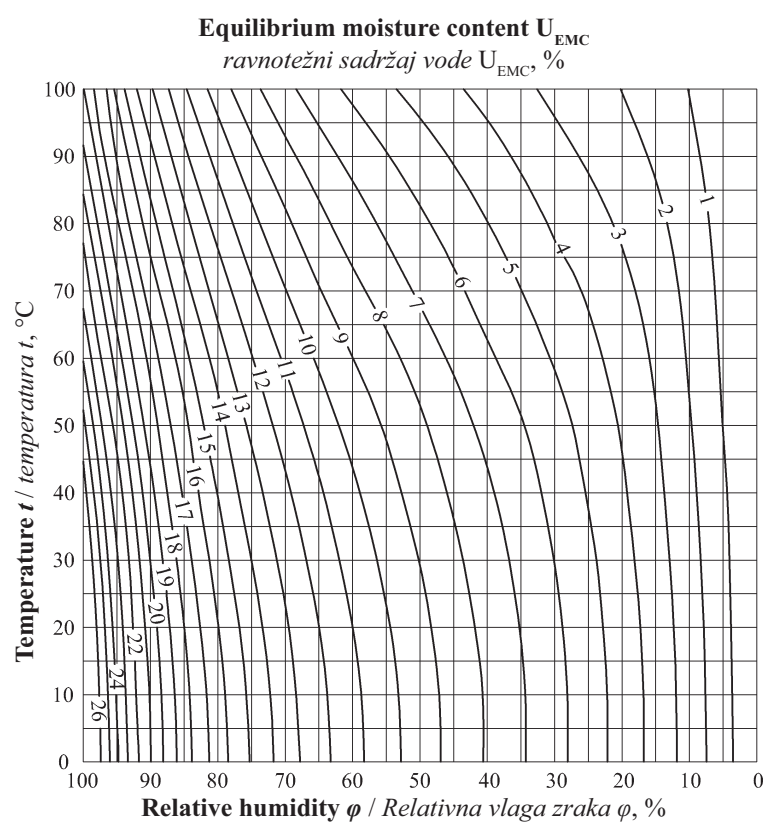

Figure 2 Change in $U_{\mathrm{EMC}}$ depending on $\varphi$ and $\mathrm{t}$, calculated according to the Simpson model at $0{ }^{\circ} \mathrm{C} \leq t \leq 50^{\circ} \mathrm{C}$ and according the Ray et al. model at $50{ }^{\circ} \mathrm{C}<t \leq 100{ }^{\circ} \mathrm{C}$

Slika 2. Promjene ravnotežnog sadržaja vode u ovisnosti o temperaturi i vlažnosti zraka, izračunane na temelju Simpsonova modela za temperature $0{ }^{\circ} \mathrm{C} \leq t \leq 50^{\circ} \mathrm{C} \mathrm{i}$ Rayeva modela za temperature $50{ }^{\circ} \mathrm{C}<t \leq 100^{\circ} \mathrm{C}$ 
Table 1 Change of the calculated and their corresponding experimentally established values of $U_{\text {EMC }}$ depending on $t$ and $\varphi$ within the range $0 \leq t \leq 100^{\circ} \mathrm{C}$ and $0 \leq \varphi \leq 50 \%$

Tablica 1. Razlike između izračunane i odgovarajuće eksperimentalno dobivene vrijednosti ravnotežnog sadržaja vode u ovisnosti o temperaturi i vlažnosti zraka u rasponu $0 \leq t \leq 100^{\circ} \mathrm{C}$ i $0 \leq \varphi \leq 50 \%$

\begin{tabular}{|c|c|c|c|c|c|c|c|c|}
\hline \multirow{3}{*}{$\begin{array}{c}\text { Temperature } \\
\text { Temperatura } \\
t,{ }^{\circ} \mathrm{C}\end{array}$} & \multicolumn{7}{|c|}{ Computed values of $U_{\mathrm{EMC}}, \%$ / Izračunana vrijednost $U_{\mathrm{EMC}}, \%$} & \multirow{2}{*}{$\begin{array}{c}\text { Experimental values } \\
\text { Eksperimentalna } \\
\text { vrijednost } U_{\mathrm{EMC}} \%\end{array}$} \\
\hline & $\begin{array}{c}\text { H \& H-2 } \\
(1946)\end{array}$ & $\begin{array}{c}\mathrm{M} \\
(1958)\end{array}$ & $\begin{array}{l}\text { D \& N } \\
(1965)\end{array}$ & $\begin{array}{c}\mathrm{K} \\
(1972)\end{array}$ & $\begin{array}{c}\mathrm{S} \\
(1991)\end{array}$ & $\begin{array}{c}\mathrm{G} \\
(2002)\end{array}$ & $\begin{array}{l}\text { R et al. } \\
(2007)\end{array}$ & \\
\hline & \multicolumn{8}{|c|}{ Relative air humidity $\varphi=0 \%$ / Relativna vlažnost zraka $\varphi=0 \%$} \\
\hline 0 & 0.0 & 0.0 & 0.0 & 3.27 & 0.0 & 0.0 & 126.2 & 0.0 \\
\hline 25 & 0.0 & 0.0 & 0.0 & 2.89 & 0.0 & 0.0 & 7.23 & 0.0 \\
\hline 50 & 0.0 & 0.0 & 0.0 & 2.52 & 0.0 & 0.0 & 0.02 & 0.0 \\
\hline 100 & 0.0 & 0.0 & 0.0 & 1.77 & 0.0 & 0.0 & 0.33 & 0.0 \\
\hline \multicolumn{9}{|c|}{ Relative air humidity $\varphi=10 \%$ / Relativna vlažnost zraka $\varphi=10 \%$} \\
\hline 15.6 & 2.6 & 2.8 & 3.2 & 3.8 & 2.5 & 2.3 & 19.0 & $2.5^{*}$ \\
\hline 26.7 & 2.3 & 2.6 & 2.8 & 3.6 & 2.4 & 2.2 & 7.0 & 2.4 \\
\hline 35.0 & 2.1 & 2.4 & 2.6 & 3.5 & 2.3 & 2.1 & 3.6 & 2.3 \\
\hline 48.9 & 1.9 & 2.2 & 2.3 & 3.2 & 2.1 & 2.0 & 2.1 & 2.3 \\
\hline 65.6 & 1.6 & 2.0 & 1.9 & 2.9 & 1.8 & 1.9 & 2.6 & $2.2^{*}$ \\
\hline \multicolumn{9}{|c|}{ Relative air humidity $\varphi=20 \%$ / Relativna vlažnost zraka $\varphi=20 \%$} \\
\hline 26.7 & 4.2 & 4.2 & 4.7 & 4.6 & 4.4 & 3.8 & 8.0 & 4.5 \\
\hline 35.0 & 3.9 & 4.0 & 4.4 & 4.4 & 4.2 & 3.7 & 5.5 & 4.0 \\
\hline 46.1 & 3.6 & 3.7 & 4.0 & 4.1 & 4.0 & 3.6 & 4.0 & 3.9 \\
\hline 60.0 & 3.2 & 3.4 & 3.5 & 3.8 & 3.6 & 3.3 & 3.4 & $3.5^{*}$ \\
\hline 71.1 & 3.0 & 3.2 & 3.1 & 3.5 & 3.2 & 3.2 & 3.1 & $3.1 *$ \\
\hline \multicolumn{9}{|c|}{ Relative air humidity $\varphi=30 \% /$ Relativna vlažnost zraka $\varphi=30 \%$} \\
\hline 29.4 & 5.7 & 5.6 & 6.3 & 5.7 & 6.0 & 5.3 & 8.1 & 6.0 \\
\hline 35.0 & 5.5 & 5.4 & 6.1 & 5.6 & 5.9 & 5.2 & 7.0 & 5.7 \\
\hline 43.3 & 5.2 & 5.1 & 5.7 & 5.3 & 5.6 & 5.0 & 5.9 & 5.4 \\
\hline 60.0 & 4.6 & 4.6 & 4.9 & 4.8 & 5.0 & 4.7 & 4.8 & 4.8 \\
\hline 87.8 & 3.8 & 3.9 & 3.8 & 4.0 & 3.8 & 4.0 & 3.4 & 3.3 \\
\hline \multicolumn{9}{|c|}{ Relative air humidity $\varphi=40 \% /$ Relativna vlažnost zraka $\varphi=40 \%$} \\
\hline 35.0 & 6.9 & 6.8 & 7.8 & 7.1 & 7.3 & 6.7 & 8.2 & $7.2^{*}$ \\
\hline 43.3 & 6.5 & 6.4 & 7.3 & 6.7 & 7.0 & 6.5 & 7.3 & 6.8 \\
\hline 48.9 & 6.3 & 6.2 & 7.0 & 6.5 & 6.8 & 6.4 & 6.8 & 6.6 \\
\hline 60.0 & 5.9 & 5.8 & 6.4 & 6.1 & 6.3 & 6.0 & 6.1 & 6.0 \\
\hline 82.2 & 5.1 & 5.1 & 5.3 & 5.2 & 5.2 & 5.3 & 4.8 & 4.8 \\
\hline \multicolumn{9}{|c|}{ Relative air humidity $\varphi=50 \%$ / Relativna vlažnost zraka $\varphi=50 \%$} \\
\hline 40.6 & 8.0 & 8.0 & 9.2 & 8.7 & 8.6 & 8.2 & 9.0 & 8.7 \\
\hline 46.1 & 7.8 & 7.8 & 8.9 & 8.4 & 8.3 & 8.0 & 8.5 & 8.2 \\
\hline 60.0 & 7.2 & 7.2 & 8.0 & 7.7 & 7.7 & 7.5 & 7.5 & $7.5^{*}$ \\
\hline 82.2 & 6.3 & 6.3 & 6.8 & 6.6 & 6.5 & 6.6 & 6.0 & 6.0 \\
\hline 98.9 & 5.8 & 5.8 & 5.9 & 5.8 & 5.4 & 5.8 & 4.7 & 5.1 \\
\hline
\end{tabular}

\subsection{Change of $U_{\mathrm{EMC}}$ within the range $100 \leq t \leq 200^{\circ} \mathrm{C}$}

3.2. Promjene $U_{\text {EMC }}$ u rasponu temperatura $100 \leq t \leq 200^{\circ} \mathrm{C}$

The values of $U_{\mathrm{EMC}}$ calculated using the models 3, 4, 6, 7 and 9 and their corresponding experimental values from FPL (1999) and Kubojima et al. (2003) are given in Table 3 within the range $100{ }^{\circ} \mathrm{C} \leq t \leq 150{ }^{\circ} \mathrm{C}$ and $10 \% \leq \varphi \leq 85 \%$.

The comparison of the calculated and experimental results, partly presented in Table 3 , shows that the experimentally established change of $U_{\text {EMC }}$ depending on $t$ and $\varphi$ is most accurately described by the Garsía model. Fig. 3 shows the isotherms of $U_{\text {EMC }}$ built using this model when $t=100,120,140,160,180$ and $200{ }^{\circ} \mathrm{C}$ with the change of $\varphi$ ranging from $0 \%$ to $100 \%$.

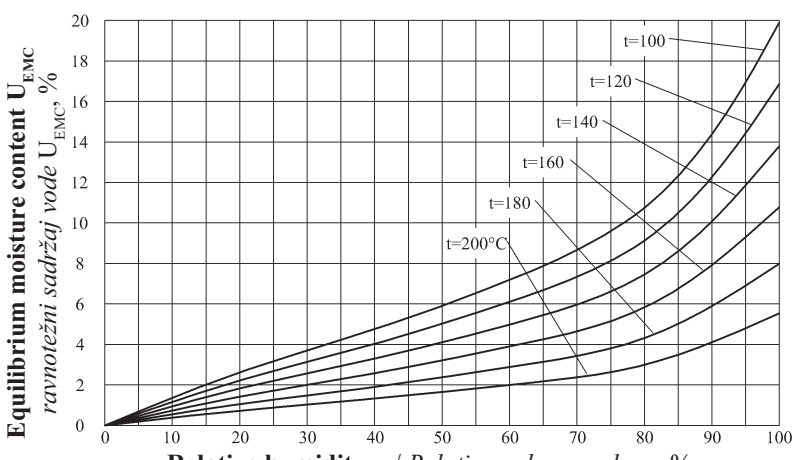

Relative humidity $\varphi$ / Relativna vlaga zraka $\varphi, \%$

Figure 3 Change in $U_{\text {EMC }}$ depending on $\varphi$ and $t$, calculated based on Garsía model

Slika 3. Promjene ravnotežnog sadržaja vode u ovisnosti o temperaturi i vlažnosti zraka, izračunane na temelju Garsíjeva modela za temperature $0{ }^{\circ} \mathrm{C} \leq t \leq 50{ }^{\circ} \mathrm{C}$ 
Table 2 Change of the calculated values and their corresponding experimentally established values of $U_{\text {EMC }}$ depending on $t$ and $\varphi$ within the ranges $0 \leq t \leq 100^{\circ} \mathrm{C}$ and $60 \leq \varphi \leq 94 \%$

Tablica 2. Razlike između izračunane i odgovarajuće eksperimentalno dobivene vrijednosti ravnotežnog sadržaja vode u ovisnosti o temperaturi i vlažnosti zraka u rasponu $0 \leq t \leq 100{ }^{\circ} \mathrm{C}$ i $60 \leq \varphi \leq 94 \%$

\begin{tabular}{|c|c|c|c|c|c|c|c|c|}
\hline \multirow{3}{*}{$\begin{array}{c}\text { Temperature } \\
\text { Temperatura } \\
t,{ }^{\circ} \mathrm{C}\end{array}$} & \multicolumn{7}{|c|}{ Computed values of $U_{\mathrm{EMC}}, \%$ / Izračunana vrijednost $U_{\mathrm{EMC}}, \%$} & \multirow{2}{*}{$\begin{array}{c}\text { Experimental values } \\
\text { Eksperimentalna } \\
\text { vrijednost } U_{\mathrm{EMC}} \%\end{array}$} \\
\hline & $\begin{array}{c}\mathrm{H} \& \mathrm{H}-2 \\
(1946)\end{array}$ & $\begin{array}{c}\mathrm{M} \\
(1958)\end{array}$ & $\begin{array}{l}\mathrm{D} \& \mathrm{~N} \\
(1965)\end{array}$ & $\begin{array}{c}\mathrm{K} \\
(1972)\end{array}$ & $\begin{array}{c}\mathrm{S} \\
(1991)\end{array}$ & $\begin{array}{c}\mathrm{G} \\
(2002)\end{array}$ & $\begin{array}{l}\text { R et al. } \\
(2007)\end{array}$ & \\
\hline & \multicolumn{8}{|c|}{ Relative air humidity $\varphi=60 \%$ / Relativna vlažnost zraka $\varphi=60 \%$} \\
\hline 12.8 & 11.5 & 11.4 & 13.1 & 12.7 & 11.2 & 10.9 & 14.5 & 11.0 \\
\hline 40.6 & 9.6 & 9.7 & 11.2 & 11.0 & 10.2 & 10.0 & 10.6 & 10.3 \\
\hline 54.4 & 8.9 & 9.0 & 10.3 & 10.1 & 9.5 & 9.4 & 9.4 & 9.4 \\
\hline 71.1 & 8.1 & 8.2 & 9.1 & 9.1 & 8.5 & 8.6 & 8.1 & 8.2 \\
\hline 87.8 & 7.4 & 7.5 & 8.0 & 8.0 & 7.5 & 7.8 & 6.8 & 7.0 \\
\hline 98.9 & 7.0 & 7.1 & 7.4 & 7.4 & 6.7 & 7.2 & 5.9 & 6.3 \\
\hline 110.0 & 6.7 & 6.7 & 6.7 & 6.7 & 5.8 & 6.6 & 4.7 & 5.7 \\
\hline \multicolumn{9}{|c|}{ Relative air humidity $\varphi=70 \% /$ Relativna vlažnost zraka $\varphi=70 \%$} \\
\hline 12.8 & 13.7 & 13.6 & 15.6 & 16.1 & 13.4 & 13.3 & 18.3 & 13.4 \\
\hline 37.8 & 11.7 & 11.9 & 13.8 & 14.1 & 12.3 & 12.2 & 13.0 & 12.4 \\
\hline 43.3 & 11.4 & 11.6 & 13.4 & 13.7 & 12.0 & 12.0 & 12.4 & 12.0 \\
\hline 51.7 & 10.9 & 11.1 & 12.7 & 13.0 & 11.5 & 11.6 & 11.5 & 11.5 \\
\hline 65.6 & 10.1 & 10.3 & 11.7 & 11.9 & 10.6 & 10.8 & 10.3 & 10.3 \\
\hline 82.2 & 9.4 & 9.5 & 10.4 & 10.6 & 9.5 & 9.8 & 9.0 & 9.0 \\
\hline 98.9 & 8.7 & 8.8 & 9.2 & 9.3 & 8.3 & 8.8 & 7.4 & 8.0 \\
\hline \multicolumn{9}{|c|}{ Relative air humidity $\varphi=80 \% /$ Relativna vlažnost zraka $\varphi=80 \%$} \\
\hline 10.0 & 17.0 & 16.8 & 19.0 & 20.6 & 16.4 & 16.6 & 28.0 & 16.3 \\
\hline 37.8 & 14.4 & 14.6 & 16.9 & 17.9 & 15.1 & 15.0 & 16.3 & 15.0 \\
\hline 48.9 & 13.6 & 13.9 & 15.9 & 16.8 & 14.4 & 14.4 & 14.6 & 14.1 \\
\hline 65.6 & 12.6 & 12.8 & 14.5 & 15.1 & 13.1 & 13.3 & 12.9 & 13.0 \\
\hline 87.8 & 11.5 & 11.6 & 12.6 & 12.9 & 11.4 & 11.7 & 10.8 & 10.9 \\
\hline 98.9 & 11.0 & 11.0 & 11.7 & 11.8 & 10.4 & 10.8 & 9.6 & $10.3^{*}$ \\
\hline 101.7 & 10.9 & 10.9 & 11.5 & 11.5 & 10.2 & 10.6 & 9.3 & 9.8 \\
\hline \multicolumn{9}{|c|}{ Relative air humidity $\varphi=90 \% /$ Relativna vlažnost zraka $\varphi=90 \%$} \\
\hline 43.3 & 18.2 & 18.4 & 21.1 & 21.9 & 19.1 & 18.9 & 20.1 & 19.0 \\
\hline 51.7 & 17.6 & 17.8 & 20.3 & 20.9 & 18.4 & 18.2 & 18.6 & $18.3^{*}$ \\
\hline 65.6 & 16.6 & 16.8 & 19.0 & 19.1 & 17.2 & 17.1 & 17.0 & 16.6 \\
\hline 87.8 & 15.3 & 15.4 & 16.8 & 16.4 & 15.1 & 15.0 & 14.5 & 14.2 \\
\hline 98.9 & 14.8 & 14.7 & 15.7 & 15.0 & 14.0 & 13.9 & 13.2 & 13.8 \\
\hline 101.7 & 14.7 & 14.5 & 15.4 & 14.6 & 13.7 & 13.6 & 12.9 & 13.5 \\
\hline \multicolumn{9}{|c|}{ Relative air humidity $\varphi=94 \% /$ Relativna vlažnost zraka $\varphi=94 \%$} \\
\hline 48.9 & 20.3 & 20.6 & 23.8 & 23.3 & 21.2 & 20.9 & 21.4 & 21.3 \\
\hline 54.4 & 19.9 & 20.2 & 23.2 & 22.6 & 20.7 & 20.4 & 20.5 & 21.0 \\
\hline 82.2 & 18.0 & 18.3 & 20.3 & 18.7 & 18.0 & 17.6 & 17.2 & 17.3 \\
\hline 87.8 & 17.8 & 17.9 & 19.7 & 18.0 & 17.4 & 17.0 & 16.5 & 16.9 \\
\hline 92.3 & 17.5 & 17.6 & 19.2 & 17.4 & 17.0 & 16.5 & 16.0 & 16.4 \\
\hline 98.9 & 17.2 & 17.2 & 18.5 & 16.4 & 16.2 & 15.7 & 15.3 & 16.0 \\
\hline
\end{tabular}

In the contemporary model-based and model predictive systems for automatic control of high temperature processes for wood hydrothermal treatment (e.g. veneer drying), it is required to compute continuously the set values of $U_{\mathrm{EMC}}$ in the temperature range from $0{ }^{\circ} \mathrm{C}$ to $200{ }^{\circ} \mathrm{C}$. For ensuring this requirement, the evaluation of the validity of the models has been extrapolated to $200^{\circ} \mathrm{C}$ in Fig. 3.

The comparison of the results calculated based on the Garsía model at $t=100{ }^{\circ} \mathrm{C}$ as shown in Table 3, with the precisely analogous results in Fig. 2 having the same temperature obtained based on the Ray et al. model, show that the Garsía model gives higher values of $U_{\text {EMC }}$ within the whole range of change of $\varphi$. Table 3 clearly shows that the calculated values of $U_{\mathrm{EMC}}$ based on the Garsía model are higher than their corresponding values of $U_{\text {EMC }}$ in all the examined values of $t \geq$ $100{ }^{\circ} \mathrm{C}$.

In order to increase the precision of the Garsía model and for a better qualitative and quantitative coordination of the calculated values of $U_{\text {EMC }}$ when $t \geq$ $100{ }^{\circ} \mathrm{C}$ with the values of $U_{\mathrm{EMC}}$ based on the Ray et al. model within the range $50{ }^{\circ} \mathrm{C}<t \leq 100{ }^{\circ} \mathrm{C}$, we suggest adding a power coefficient of 1.33 to the denominator on the right side of the equation (17). Then the equation (17) becomes:

$$
U_{\mathrm{EMC}}=K\left[\left(\frac{K_{5}}{\varphi^{1.33}}\right)^{K_{7}}-1\right]^{-\frac{1}{K_{6}}}
$$


Table 3 Change of the calculated values and their corresponding experimentally established values of $U_{\text {EMC }}$ depending on $t$ and $\varphi$ within the range $100{ }^{\circ} \mathrm{C} \leq \mathrm{t} \leq 150{ }^{\circ} \mathrm{C}$ and $0 \% \leq \varphi \leq 85 \%$

Tablica 3. Razlike između izračunane i odgovarajuće eksperimentalno dobivene vrijednosti ravnotežnog sadržaja vode u ovisnosti o temperaturi i vlažnosti zraka u rasponu $100{ }^{\circ} \mathrm{C} \leq t \leq 150{ }^{\circ} \mathrm{C}$ i $0 \% \leq \varphi \leq 85 \%$

\begin{tabular}{|c|c|c|c|c|c|c|c|}
\hline \multirow{2}{*}{$\begin{array}{c}\text { Temperature } \\
\text { Temperatura } \\
t,{ }^{\circ} \mathrm{C}\end{array}$} & \multicolumn{6}{|c|}{ Computed values of $U_{\mathrm{EMC}}, \%$ / Izračunana vrijednost $U_{\mathrm{EMC}}, \%$} & \multirow{2}{*}{$\begin{array}{c}\text { Experimental } \\
\text { values } \\
\text { Eksperimentalna } \\
\text { vrijednost } U_{\mathrm{EMC}} \%\end{array}$} \\
\hline & $\begin{array}{c}\text { Hailwood\& } \\
\text { Horrobin-2 } \\
\quad(1946 \\
\end{array}$ & $\begin{array}{l}\text { Malmquist } \\
\text { (1958) }\end{array}$ & $\begin{array}{c}\text { Day\&Nelson } \\
(1965)\end{array}$ & $\begin{array}{c}\text { Kaplan } \\
(1972)\end{array}$ & $\begin{array}{l}\text { Garsía } \\
(2002)\end{array}$ & $\begin{array}{l}\text { Garsía- } \\
\text { Deliiski }\end{array}$ & \\
\hline \multicolumn{8}{|c|}{ Relative air humidity $\varphi=10 \% /$ Relativna vlažnost zraka $\varphi=10 \%$} \\
\hline 100 & 1.21 & 1.63 & 1.23 & 2.24 & 1.50 & 0.83 & $1.0^{*}$ \\
\hline 110 & 1.10 & 1.54 & 1.09 & 2.05 & 1.39 & 0.77 & $0.9^{*}$ \\
\hline 120 & 1.01 & 1.45 & 0.95 & 1.86 & 1.28 & 0.70 & $0.8^{*}$ \\
\hline 130 & 0.92 & 1.37 & 0.83 & 1.67 & 1.16 & 0.64 & - \\
\hline 140 & 0.83 & 1.30 & 0.73 & 1.48 & 1.04 & 0.57 & - \\
\hline 150 & 0.75 & 1.22 & 0.63 & 1.29 & 0.93 & 0.51 & - \\
\hline \multicolumn{8}{|c|}{ Relative air humidity $\varphi=20 \% /$ Relativna vlažnost zraka $\varphi=20 \%$} \\
\hline 100 & 2.4 & 2.7 & 2.3 & 2.8 & 2.6 & 1.7 & $2.3^{*}$ \\
\hline 110 & 2.2 & 2.5 & 2.1 & 2.6 & 2.4 & 1.6 & $2.0^{*}$ \\
\hline 120 & 2.1 & 2.4 & 1.8 & 2.4 & 2.2 & 1.4 & $1.7^{*}$ \\
\hline 130 & 1.9 & 2.2 & 1.6 & 2.1 & 2.0 & 1.3 & $1.5^{*}$ \\
\hline 140 & 1.7 & 2.1 & 1.4 & 1.9 & 1.8 & 1.2 & - \\
\hline 150 & 1.6 & 2.0 & 1.3 & 1.6 & 1.6 & 1.1 & - \\
\hline \multicolumn{8}{|c|}{ Relative air humidity $\varphi=40 \%$ / Relativna vlažnost zraka $\varphi=40 \%$} \\
\hline 100 & 4.6 & 4.7 & 4.5 & 4.5 & 4.8 & 3.6 & $4.2 *$ \\
\hline 110 & 4.3 & 4.4 & 4.1 & 4.2 & 4.4 & 3.4 & $3.6^{*}$ \\
\hline 120 & 4.1 & 4.2 & 3.7 & 3.8 & 4.0 & 3.1 & $3.2^{*}$ \\
\hline 130 & 3.8 & 4.0 & 3.4 & 3.4 & 3.7 & 2.8 & $2.9^{*}$ \\
\hline 140 & 3.6 & 3.7 & 3.0 & 3.0 & 3.3 & 2.5 & - \\
\hline 150 & 3.4 & 3.5 & 2.7 & 2.6 & 2.9 & 2.2 & - \\
\hline \multicolumn{8}{|c|}{ Relative air humidity $\varphi=60 \%$ / Relativna vlažnost zraka $\varphi=60 \%$} \\
\hline 100 & 7.0 & 7.1 & 7.3 & 7.3 & 7.2 & 6.0 & $6.3^{*}$ \\
\hline 110 & 6.7 & 6.7 & 6.7 & 6.7 & 6.7 & 5.5 & $5.7^{*}$ \\
\hline 120 & 6.4 & 6.4 & 6.2 & 6.1 & 6.1 & 5.1 & - \\
\hline 130 & 6.1 & 6.1 & 5.6 & 5.4 & 5.5 & 4.6 & - \\
\hline 140 & 5.8 & 5.8 & 5.1 & 4.8 & 5.0 & 4.1 & - \\
\hline 150 & 5.5 & 5.5 & 4.7 & 4.2 & 4.4 & 3.7 & - \\
\hline \multicolumn{8}{|c|}{ Relative air humidity $\varphi=85 \%$ / Relativna vlažnost zraka $\varphi=85 \%$} \\
\hline 100 & 12.6 & 12.5 & 13.3 & 13.2 & 12.1 & 10.9 & $11.7 *$ \\
\hline 110 & 12.1 & 12.0 & 12.4 & 12.1 & 11.2 & 10.1 & 9.9 \\
\hline 120 & 11.7 & 11.5 & 11.5 & 10.9 & 10.3 & 9.2 & 7.8 \\
\hline 125 & 11.5 & 11.2 & 11.1 & 11.5 & 9.8 & 8.8 & 7.5 \\
\hline 130 & 11.3 & 11.0 & 10.7 & 9.8 & 9.3 & 8.4 & 6.9 \\
\hline 135 & 11.2 & 10.7 & 10.3 & 9.3 & 8.8 & 8.0 & 5.9 \\
\hline 140 & 11.0 & 10.5 & 9.9 & 8.7 & 8.4 & 7.5 & 5.2 \\
\hline 145 & 10.8 & 10.3 & 9.5 & 8.1 & 7.9 & 7.1 & 4.5 \\
\hline 150 & 10.7 & 10.1 & 9.1 & 7.6 & 7.5 & 6.7 & 4.4 \\
\hline
\end{tabular}

The column before the last one in Table 3 presents the obtained results of the change of $U_{\mathrm{EMC}}$ based on the so-called Garsía-Deliiski model, which consists of both equations (25) and (18). The comparison of these results with the experimental data, presented on the right in Table 3 , shows a significant reduction of the absolute errors of $U_{\text {EMC }}$ when $U_{\text {EMC }}$ is calculated according to the absolute errors obtained by Garsía model (17) and (18).

Fig. 4 shows isotherms of the change of $U_{\text {EMC }}$, with full lines, obtained based on the Garsía model, and their analogues, calculated based on the GarsíaDeliiski model, shown with dotted lines. In the present paper the proposed Garsía-Deliiski model, which con- sists of equation (25) and (18), precisely reflects qualitatively and quantitatively the relation of $U_{\mathrm{EMC}}$ depending on $\varphi$ and $t$ within the range from $100{ }^{\circ} \mathrm{C}$ to $200{ }^{\circ} \mathrm{C}$. A future clarification of this model should be made when having extensive experimental data for the change in $U_{\text {EMC }}$ depending on $t$ and $\varphi$ within this temperature range.

Fig. 5 shows for the first time the summarized diagram of the change in $U_{\text {EMC }}$ depending on $\varphi$ and $t$ within the range $0 \% \leq \varphi \leq 100 \%$ and $0{ }^{\circ} \mathrm{C}<t \leq 200{ }^{\circ} \mathrm{C}$. The curves are built based on the results obtained by the Simpson model at temperatures $0{ }^{\circ} \mathrm{C} \leq t \leq 50{ }^{\circ} \mathrm{C}$, by the Ray et al. model at $50{ }^{\circ} \mathrm{C}<t \leq 100^{\circ} \mathrm{C}$ and by the Garsía-Deliiski model at $100^{\circ} \mathrm{C}<t \leq 200^{\circ} \mathrm{C}$. 


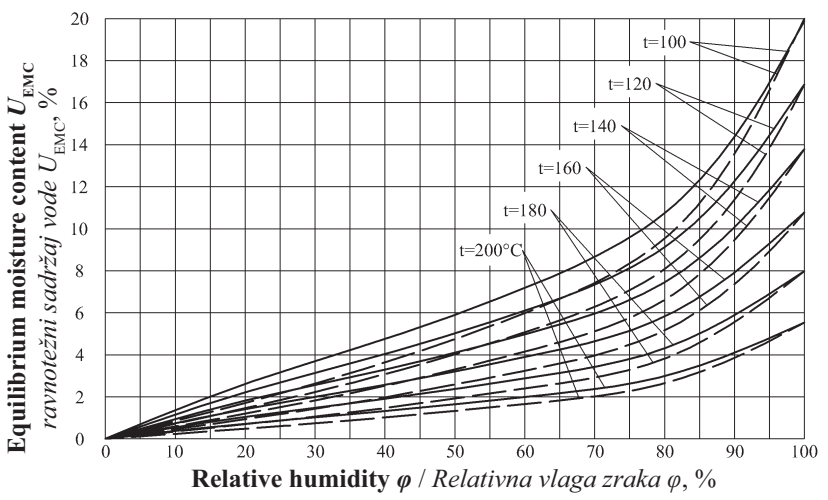

Figure 4 Change in $U_{\text {EMC }}$ depending on both $\varphi$ and $t$, calculated using the Garsía model - full lines, and using the Garsía-Deliiski model - dotted lines

Slika 4. Promjene ravnotežnog sadržaja vode u ovisnosti o temperaturi i vlažnosti zraka, izračunane na temelju Garsíjeva modela (pune linije) i Garsía-Deliiskijeva modela (iscrtkane linije)

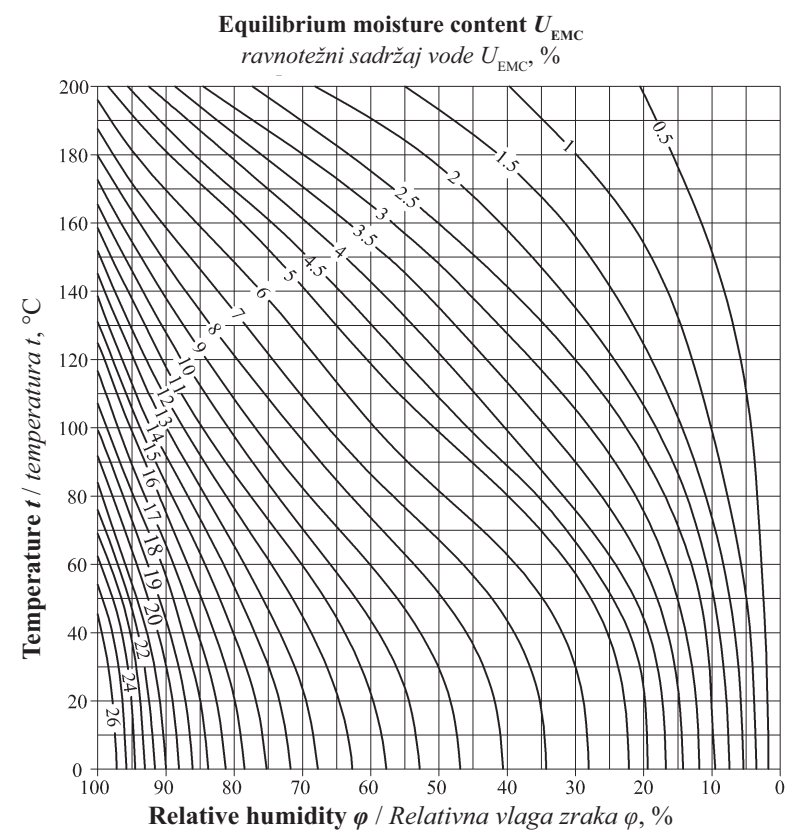

Figure 5 Change in $U_{\mathrm{EMC}}$ depending on $\varphi$ and $t$, calculated by the Simpson model at $0{ }^{\circ} \mathrm{C} \leq t \leq 50^{\circ} \mathrm{C}$, by the Ray et al. model at $50{ }^{\circ} \mathrm{C}<t \leq 100{ }^{\circ} \mathrm{C}$ and by the Garsía-Deliiski model at $100{ }^{\circ} \mathrm{C}<t \leq 200{ }^{\circ} \mathrm{C}$

Slika 5. Promjene ravnotežnog sadržaja vode u ovisnosti o temperaturi i vlažnosti zraka, izračunane na temelju Simpsonova modela za temperature $0{ }^{\circ} \mathrm{C} \leq t \leq 50{ }^{\circ} \mathrm{C}$, Rayeva modela za temperature $50{ }^{\circ} \mathrm{C}<t \leq 100{ }^{\circ} \mathrm{C}$ i GarsíaDeliiskijeva modela za temperature $100{ }^{\circ} \mathrm{C}<t \leq 200{ }^{\circ} \mathrm{C}$

\section{CONCLUSIONS}

\section{ZAKLJUČCl}

The present paper describes the evaluation of the precision of the 10 most often used wood sorption models, available in the literature, for the calculation of wood equilibrium moisture content $U_{\text {EMC }}$ given a change in temperature within the range from $0{ }^{\circ} \mathrm{C}$ to $200{ }^{\circ} \mathrm{C}$ and in relative humidity $\varphi$ of the surrounding air environment from $0 \%$ to $100 \%$. The calculated results were compared to corresponding precise experimental data from the literature.
The obtained results show that the Simpson model gave the best fit to experimental data for the range $0{ }^{\circ} \mathrm{C} \leq t \leq 50{ }^{\circ} \mathrm{C}$. The best precision within the range $50{ }^{\circ} \mathrm{C}<t \leq 100^{\circ} \mathrm{C}$ was provided by the Ray et al. model and within the range $100{ }^{\circ} \mathrm{C}<t \leq 150{ }^{\circ} \mathrm{C}$ by the Garsía model.

In order to increase the precision of the Garsía model and for better qualitative and quantitative coordination of the calculated values, with the help of $U_{\text {EMC }}$ at $t \geq 100^{\circ} \mathrm{C}$, with values of $U_{\mathrm{EMC}}$ based on the Ray et al. model within the range $50{ }^{\circ} \mathrm{C}<t \leq 100^{\circ} \mathrm{C}$, we suggest the clarification of the Garsía model. The clarification means introduction of a power coefficient, equaling 1.33 , to the denominator on the right side of the equation of the Garsía model.

With the results calculated from the Simpson and Ray et al. models, a diagram has been built for the change in $U_{\mathrm{EMC}}$ depending on $\varphi$ and $t$ within the ranges $0 \% \leq \varphi \leq 100 \%$ and $0{ }^{\circ} \mathrm{C} \leq t \leq 100{ }^{\circ} \mathrm{C}$. This diagram reflects the experimentally established dependency of $U_{\text {EMC }}$ on $\varphi$ and $t$ with better precision in comparison to analogous diagrams, usually found in the literature.

Using the results obtained by both the Simpson and Ray et al. models and the Garsía model, which we have refined, a summary diagram of the change in $U_{\text {EMC }}$, depending on $\varphi$ and $t$ within the range $0 \% \leq \varphi \leq$ $100 \%$ and $0{ }^{\circ} \mathrm{C} \leq t \leq 200{ }^{\circ} \mathrm{C}$, has been created for the first time. This diagram can be used for the precise determination of $U_{\text {EMC }}$ when having different temperature-humidity impacts on the wood.

The established high precision of both the Simpson and Ray et al. models and the Garsía model, which we have refined, makes them user friendly for contemporary systems for model-based and model predictive automatic control (Hadjiyski, 2003) of different processes of hydrothermal treatment of wood and wood materials. This way, for example, we have input the Simpson model into the software of the microprocessor programmable controller in order to control the temperature conditioning process of dried lumber (Fig. 6).

The long use of the implemented automated installation in the conditioning storage house (Deliiski, 2009 b) confirmed completely the validity of the calculating and controlling algorithm used in the controller. It proved its high energy efficiency, reliable functioning and suitability to assure the temperature-humidity parameters of the air, corresponding completely to the $U_{\text {EMC }}$ of the wood, required by the user.

\section{REFERENCES}

5. LITERATURA

1. Avramidis, S., 1989: Evaluation of "three-variable" models for the prediction of equilibrium moisture content wood. Wood Sci. Technol. 23: 251-258, http://dx.doi.org/10.1007/BF00367738

2. Ball, R.D.; Simpson, G.; Pang, S., 2001: Measurement, modelling and prediction of equilibrium moisture content in Pinus radiata heartwood and sapwood. Holz als Rohund Werkstoff 59(6): 457-462,

http://dx.doi.org/10.1007/s001070100242 

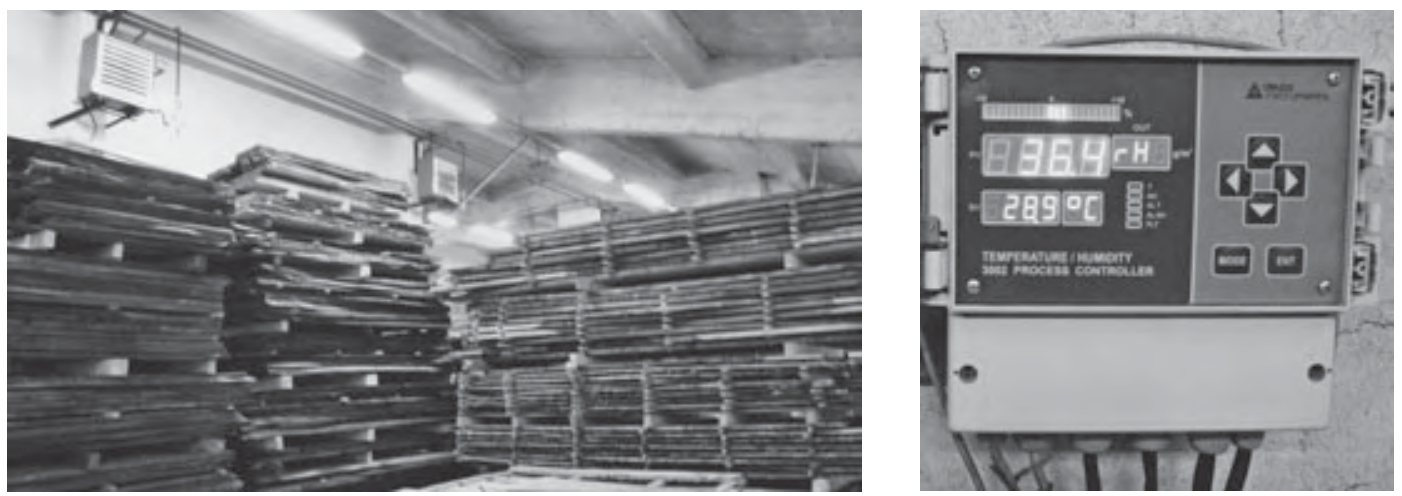

Figure 6 Automated storage house for dried wood materials (on the left) and programmable controller for automatic computation and model-based control of its conditioning process (on the right)

Slika 6. Automatizirano skladište osušenoga drvnog materijala (lijevo) i programabilni kontroler za automatsko izračunavanje parametara i na modelu utemeljeno upravljanje procesom kondicioniranja u skladištu

3. Brunauer, S.; Emmett, P.H.; Teller, E., 1938: Adsorption of gases in multi molecular layers. J. Am.Chem. Soc. 60: 309-319, http://dx.doi.org/10.1021/ja01269a023

4. Day, D. L.; Nelson, G. L., 1965: Desorption isotherms for wheat. Trans. of the ASAE. 8: 293-297.

5. Deliiski, N. 2009a: Mathematical description of the equilibrium moisture content of the wood. International scientific conference "Automatic \& Informatics", Sofia, IV-33-36 (in Bulgarian).

6. Deliiski, N., 2009b: Model based control of storage house for conditioning of dried wood materials. Automatic \& Informatics, 43 (1): 37-40 (in Bulgarian).

7. FPL. 1999: Wood Handbook. Chapter 3: Physical properties and moisture relations of wood. Forest Products Laboratory, Madison, United States, $463 \mathrm{p}$.

8. Garsía, P., 2002: Three-dimensional heat and mass transfer during oriented strand board hot-pressing. Ph.D. Thesis. University of British Columbia, Canada. $254 \mathrm{p}$.

9. Hadjiyski, M., 2003: Mathematical Models in Advanced Technological Control Systems. Automatic \& Informatics, 37, (3): 7-12 (in Bulgarian).

10. Hailwood, A. J.; Horrobin, S., 1946: Absorption of water by polymers: Analysis in terms of a simple model. Trans. Faraday Soc. 42B: 84-102, http://dx.doi.org/10.1039/tf946420b084

11. Kaplan, V. Y., 1972: Investigation of the convective drying process of the wood. PhD. Thesis. Minsk, 155 p. (in Russian).

12. King, G., 1960: Theories of multi-layer adsorption. In J.W.S. Hearle and R. H. Peters, eds., Moisture in textiles. Textile Book Publ. Inst., Inc., New York, 203 p.

13. Kubojima, Y.; Suzuki, Y.; Tonosaki, M.; Ishikawa, A., 2003: Moisture content of green wood in high temperature water vapor. Holzforshung 57(6): 634-638, http://dx.doi.org/10.1515/HF.2003.095
14. Malmquist, L., 1958: Sorption a deformation of space. Svenska Träforskningsinstitutet. Träteknik. Meddelande. 983, Stockholm.

15. Pervan, S., 2000: Priručnik za tehničko sušenje drva. Sand, Zagreb.

16. Ray, Ch. D., et al, 2007: Identification on the Relationship between Equilibrium Moisture Content, Dry Bulb Temperature, and Relative Humidity Using Regression Analysis. Wood and Fiber Science, 39(2): 299-306.

17. Simpson, W. T. (ed.), 1991: Dry Kiln Operator's Manual. Agricultural Handbook No.188, United States Department of Agriculture, Madison, WI, $274 \mathrm{p}$.

18. Shubin, G. S., 1990: Drying and Thermal Treatment of Wood, Publishing Company "Lesnaya promyshlennost", Moskow, URSS (in Russian).

19. Trebula, P.; Klement, I., 2002: Drying and Thermal Treatment of Wood. TU Zvolen, Slovakia (in Slovakian).

20. Vidal, M.; Cloutier, A., 2005. Evaluation of wood sorption models for high temperatures. Clencia y tecnología 7 (2) $63: 145-158$.

21. Videlov, H. 2003: Drying and Thermal Treatment of Wood. Publishing House of the LTU, Sofia, 335 p. (in Bulgarian).

\section{Corresponding address:}

\section{Prof. NENCHO DELIISKI, Ph.D.}

Faculty of Forest Industry

University of Forestry

10 Kliment Ohridski Blvd.

1756 Sofia, BULGARIA

e-mail: deliiski@netbg.com 